\title{
Hidden Curiculum through the Performing Arts Perspective
}

\author{
${ }^{1}$ Fery Setyaningrum, ${ }^{2}$ Heni Siswantari \\ ${ }^{1}$ fery.setyaningrum@pgsd.uad.ac.id, ${ }^{2}$ Heni.siswantari@pgsd.uad.ac.id \\ ${ }^{1,2}$ Ahmad Dahlan University
}

\begin{abstract}
The purpose of this study are to describe the hidden curriculum in general and to describe the hidden curriculum from the performance art perspective. The methodology of this study is qualitative method with an ethnographic approach. Ethnography is a method commonly used in anthropological research. It requires doing field research and researchers act as people who are studying a culture. The results of this study, the first is the existence of examples of the hidden curriculum that occur in community art groups in Patimuan Subdistrict, Cilacap Regency which develop and become non-formal and informal education in a learning process. The second one is the existence of the hidden curriculum that can be used as the platform and perspective to view the art process especially performance arts in depth.
\end{abstract}

Keyword : hidden curiculum, perspective, performance art.

\section{Introduction}

Hidden Curriculum develops into a system that is very close to the scope of education, but not really realized by the education actors. It is because the curriculum exists, carried out continuously, but not structured, so that it is not realized by the actors of art and art lovers. The development of the hidden curriculum in the non-formal aspects can be found in education in studios that are widely developed in the community. While for the development of hidden curriculum in informal education can be found in the family, where the family is the closest agent in spreading the hidden curriculum. One example of the hidden curiculum found in nonformal education is the Rampak Kendang Ragil communities in Patimuan.

In the Rampak Kendang community in Patimuan Cilacap, it is believed that there is a hidden curiculum process that occurs, and can be used as an object of deep research related to a show. In the process of art, the community of Rampak Kendang (Ragil Entertainment) developed into a people's performance art that has a place in the community in the PatimuanCilacap region. Rampak Kendang itself comes from the word "rampak" which means simultaneously or together and the "kendang" which is one type of musical instrument. Thus, the writers interpret Rampak Kendnag as a show of the drums played by several people together on a stage.

The background of the art "Rampak Kendang" appeared and survived according to a teacher at SD Negeri Patimuan 01, Ratnaningsih, as that art advisor is because the art activists want to preserve the culture in Cilacap so that they are always preserved as inheritance from their ancestors, and can become the art of the pride of the Cilacap resident. The same thing was also expressed by Mr. Warsono, as the Head of the Cilacap Office of Education and Culture, who stated that it was an effort to keep the community in the culture (by upholding the values), by displaying art in Cilacap at the opening of the Regional Sports Week, National Science Sports Olympiad, and District-level National Student Art Competition Festival. 
Based on the results of the pre-observation to the community above, the researchers believe that they can better understand and see in detail the hidden curiculum description in general through the Rampak Kendang community, and through the performance art perspective, with the various complex processes that occur until the creation of a work Rampak Kendang's art in Patimuan made the writer more intrigued and interested in studying in depth again into a scientific work.

The formulation of the problem of the author in this case is (1) How to know the hidden curriculum process in general; and (2) How to know the hidden curriculum process from the perspective of the performing arts. While the objectives of this study are (1) Describing the hidden curriculum process in general; and (2) Describing the hidden curriculum process from the performance art perspective.

\subsubsection{Reference citations}

\section{Hidden curriculum in General}

Pratiwi[1] in her scientific journals, it is said that the curriculum is one of the most decisive components in an education system, therefore the curriculum is one of the tools to achieve educational goals and simultaneously as a guide in the implementation of teaching in all types and levels of education. Judging from the concept and its implementation, the curriculum is known by several curriculum terms, namely the ideal curriculum, actual or factual curriculum, and hidden curriculum.

Jane[2], in his book, What Should We Do With a Hidden Curriculum When We Find One?: The Hidden Curriculum and Moral Education, the hidden curriculum in general can be described as a byproduct of education inside or outside of school, especially the results learned, but not explicitly stated as a goal. There are two aspects that can affect the hidden curriculum, namely the relatively fixed aspects and aspects that can change. As for the understanding of the relatively fixed aspects is the ideology, beliefs, cultural values of society that influence schools, including determining what culture is appropriate and not deserving for the nation's generation. While the aspects that can change include organizational variables, social systems, and culture[3].

\section{Performance Art}

Lono[4], in his book said that the performance is a public interaction event which is built on the principle of the unusual habit of the body technique done in theater performances as "extra daily technique", which is distinguished from "daily technique" and "virtuosic technique", greatness of body techniques on acrobatics. Performances are seen as one type of public interaction event. Where the audience is an active performer of the event, so it is necessary to give an understanding to the audience that the audience is not only acting as a spectator but also as an observer and assessor of the performance.

Lono[4] said that in a performance, players and spectators will both get experience. The experience gained from the performance, with all kinds of methods and equipment used as frames, is always more centered than experiences in everyday life. Audience and players will get experience together. This experience will not be obtained in school academics, but obtained through experience.

Based on the concept of karawitan understanding, as kendhang acts as pamurba irama or rhythm leader, as a regulator of tempo aspects, in line with the expression[5] where the kendhang (drum) is the controller of the presentation of the gending. 


\section{Related Works/Literature Review}

\begin{tabular}{|c|c|c|c|c|c|}
\hline No & Researcher & $\begin{array}{c}\text { Title of The } \\
\text { Research }\end{array}$ & $\begin{array}{c}\text { Kind of } \\
\text { Approach }\end{array}$ & Similarity & Difference \\
\hline 1 & $\begin{array}{l}\text { Poppy } \\
\text { Novitasari [6] }\end{array}$ & $\begin{array}{l}\text { The role of the } \\
\text { teacher in the } \\
\text { implementation of } \\
\text { the hidden } \\
\text { curriculum on the } \\
\text { achievement of the } \\
\text { objectives of } \\
\text { Islamic religious } \\
\text { education in MAN } 1 \\
\text { Bandar Lampung }\end{array}$ & $\begin{array}{l}\text { Qualitative } \\
\text { Research }\end{array}$ & $\begin{array}{l}\text { Equally discuss } \\
\text { about hidden } \\
\text { curriculum }\end{array}$ & $\begin{array}{l}\text { a. the object of the } \\
\text { research under } \\
\text { study } \\
\text { b. implementation } \\
\text { is related to } \\
\text { worship, } \\
\text { morality and } \\
\text { social }\end{array}$ \\
\hline 2 & $\begin{array}{l}\text { Wardizal and } \\
\text { Hendra } \\
\text { Santosa [7] }\end{array}$ & $\begin{array}{l}\text { Peran wanita dalam } \\
\text { seni pertunjukan } \\
\text { tradisional } \\
\text { Minangkabau di } \\
\text { tengah perubahan } \\
\text { kehidupan sosio } \\
\text { kultural } \\
\text { masyarakatnya }\end{array}$ & $\begin{array}{l}\text { Qualitative } \\
\text { Research }\end{array}$ & $\begin{array}{l}\text { Discussing } \\
\text { about } \\
\text { performing arts }\end{array}$ & $\begin{array}{l}\text { a. the object of the } \\
\text { research under } \\
\text { study is a } \\
\text { woman }\end{array}$ \\
\hline 3 & $\begin{array}{l}\text { Muhammad } \\
\text { Fazli Taibbin } \\
\text { Saearani, } \\
\text { Gabriel Lono } \\
\text { Lastoro } \\
\text { Simatupang[4 } \\
\text { ] }\end{array}$ & $\begin{array}{l}\text { Non-formal } \\
\text { education as culture } \\
\text { transformation } \\
\text { agent towards the } \\
\text { development of } \\
\text { clasical court dance } \\
\text { in yogyakarta, } \\
\text { indonesia }\end{array}$ & $\begin{array}{l}\text { Qualitative } \\
\text { Research }\end{array}$ & $\begin{array}{l}\text { Discussing } \\
\text { about dance } \\
\text { performing arts }\end{array}$ & $\begin{array}{l}\text { a. discussing } \\
\text { traditional } \\
\text { culture }\end{array}$ \\
\hline 4 & $\begin{array}{l}\text { Esti Rahmah } \\
\text { Pratiwi[1] }\end{array}$ & $\begin{array}{l}\text { The Influence of the } \\
\text { Hidden Curriculum } \\
\text { on Character } \\
\text { Formation Students } \\
\text { at the 'Kotabaru' } \\
\text { Syuhada Mosque IT } \\
\text { Middle School } \\
\text { Yogyakarta }\end{array}$ & $\begin{array}{l}\text { Qualitative } \\
\text { Research }\end{array}$ & $\begin{array}{l}\text { a. Hidden } \\
\text { curriculum } \\
\text { melalui } \\
\text { pembiasaan } \\
\text { b. Nilai yang } \\
\text { ditanamkan } \\
\text { sama-sama } \\
\text { berpengaruh } \\
\text { kepada } \\
\text { peserta didik } \\
\text { c. Menanamkan } \\
\text { nilai-nilai } \\
\text { karakter pada } \\
\text { peserta didik }\end{array}$ & $\begin{array}{l}\text { a. Hidden } \\
\text { curriculum tends } \\
\text { to be in } \\
\text { education } \\
\text { b. The character } \\
\text { values instilled } \\
\text { are still in the } \\
\text { aspect of } \\
\text { education, such } \\
\text { as habituation of } \\
\text { the flag } \\
\text { ceremony, 5S, } \\
\text { please help, and } \\
\text { so on } \\
\text { c. The value in the } \\
\text { form of output } \\
\text { implanted } \\
\text { affects students, } \\
\text { but these values } \\
\text { still tend to be in } \\
\text { education }\end{array}$ \\
\hline
\end{tabular}

\section{Material \& Methodology}


This research uses qualitative methods, where data will appear in the form of words and not a series of numbers, with data collection using observation, interviews, study documents and then processed and analyzed[8]. This also uses an ethnographic approach. Ethnography is a method commonly used in anthropological research, ethnographic research requires doing field research and researchers act as people who are studying a culture. Researchers must master both the concepts and techniques that will be used. In addition to obtaining objective data, the researcher must enter the community he studies[9].

1. Focus / Target of Research Study

The objective of the study in this study is to focus on the hidden curriculum of the Rampak Kendang art community in Patimuan, and focus on players in the Patimuan Cilacap art community.

2. Data Collection Techniques

Data collection techniques used in this study consisted of observations, interviews, and document studies described as follows.

3.1 Observation

Observation is done to observe and systematically record the symptoms that appear in the object of research. Observations made in this study are by looking directly at "Hidden Curriculum through the Performing Arts Perspective".

3.2 Interview

An interview is a conversation with a specific purpose[10]. The conversation is carried out by both parties, namely the interviewer, the person who gives the question with the interviewee or who answers the question. The interviews conducted in this study were open interviews, the informants were free to express answers. The interviews were aimed at informants which included artists, the arts community, and the community as art lovers, and DISPARBUD

3.3 Study of Document

Study of documents carried out in the form of collecting and reviewing documents related to "Hidden Curriculum through the Performing Arts Perspective".

\section{Results and Discussion}

The curriculum is one of the most decisive components in an education system, therefore the curriculum is one of the tools to achieve educational goals and at the same time as a guide in the implementation of teaching in all types and levels of education in terms of concepts and implementation. Curriculum is known with several curriculum terms, namely the ideal curriculum, actual or factual curriculum, and hidden curriculum. Hidden curriculum is theoretically very rational influencing students, both regarding the environment, the atmosphere of space, patterns of interaction, coaches with students in the room, even in the management policies and management where the education takes place more widely. In accordance with the concept above and related to existing field data, it is clear that the success of the existence of Rampak Kendang so far will not be possible without the pattern and structure in the learning process, namely a curriculum, but the existing curriculum is not tangible, existing but not structured so can be called a hidden curriculum. One of the aspects that influence the hidden curiculum structure is students, namely music players and dancers in the Ragil Entertainment community (whether concerning the environment in the learning process, the atmosphere in learning, patterns of interaction between players and dancers, or the interaction of trainers with students in space, even in existing policies and management of Ragil Entertainment). 
The existing curriculum is in the form of non-formal and informal aspects, within the scope of the family at home and the community at large. Hidden curriculum develops into a system that is very close to the scope of education but not realized in reality. The development of the hidden curriculum in the non-formal aspects can be found in education in studios that are widely developed in the community. It is such the artist community of Rampak Kendang, while for the development of Hidden Curriculum in informal education can be found in the family, where the family is the closest agent in its spread. In this case, non-formal education in the community will not run without the support of the artists' parents.

The education in the studio which acts as a non-formal hidden curriculum, can be proven and known by the presence of reward and punishment. Where reward and punishment are reciprocity obtained when in an actors are able to show good performance and vice versa. These rewards and punishments can be done without being visited by people who get them. Punishment that is done can be in the form of harsh words that tend to be rough, but this is not intended as a mere mockery but as a motivation and mental booster. This kind of thing will not be known in real and clear that the hidden curriculum is being carried out.

Hidden curriculum in general can be described as a byproduct of education inside or outside of school, especially the results learned, but not explicitly stated as an objective. There are two aspects that can affect the hidden curriculum, namely the relatively fixed aspects and aspects that can change. As for what is meant by the relatively fixed aspect is the ideology, beliefs, cultural values of society that influence the educational institution, including determining what culture is appropriate and not deserving of the nation's generation. One example that occurs in the Ragil Entertainment community is its ability. While the aspects that can change include supporting organizational variables, social and cultural systems of the art community object, social interaction and close relations, culture by participating in preserving Rampak Kendang and being learned by many children.

Hidden curriculum also appears to be applied in the Rampak Kendang Patimuan community. The application of hidden curriculum in this community appears when children attend training activities. The training activities were carried out with character education that was not directly realized by children. Children are taught to take the time discipline towards training activities which will make children appreciate the time available. In addition, mental reinforcement for them is not ashamed to ask questions and show abilities in front of the public. This makes children easy to get along with and able to place themselves anywhere because they have the courage that is taught through the hidden curiculum.

The music of Patimuan's Rampak Kendang is a blend of Banyumasan (Central Java) and Sundanese (West Java) music styles. The musical instruments that complement the Banyumas element consists of slompret, a set of gamelan ensembles, including; saron penerus, saron barung, saron demung, bonang barung, bonang penerus, and gong. The set of gamelan is the same form in accompanying ebeg (the banyumasan kuda lumping art) and the last musical instrument which is the core element of the show is kendang, as the embodiment of Sundanese musical instruments.

\section{Conclusion}

Hidden curriculum is a term of hidden curriculum, where in general the curriculum itself is one of the most decisive components in an education system and as a guide in the implementation of teaching. Hidden curriculum can be said to be a curriculum that is structurally invisible, but becomes a habit in communities within the community. This can be seen from how the activities in the studio apply. Then in terms of the concept and its implementation, the curriculum is known by several terms, namely the ideal curriculum, 
actual or factual curriculum, and hidden curriculum. Hidden curriculum is theoretically very rational influencing students, both regarding the environment, space atmosphere, interaction patterns, coaches with students in the room, even on policies and management management where education takes place more widely. Finally the curriculum implemented in the field is not intangible, there are but not structured so that it can be called a hidden curriculum. Hidden curriculum develops into a system that is very close to the scope of education but not really realized.

One example of the hidden curriculum process that occurs in performing arts is music players and dancers in the Ragil Entertaiment community (both concerning the environment in the learning process, the atmosphere of the room in learning, the patterns of interaction between players and dancers, and the interaction of trainers with students in the room even on existing policies and management of Ragil Entertainment). The development of the hidden curriculum in the non-formal aspects can be found in studios that are widely developed in the community environment, one example is the art community of Rampak Kendang, while for the development of Hidden Curriculum in informal education can be found in the family.

Activities in the Rampak Kendang art community are non-formal hidden curriculum, which can be proven and known by the presence of reward and punishment. These rewards and punishments can be done without realizing it by people who get them. The connection with the performing arts is how the players and administrators manage the hidden curriculum as one of the principles in developing these activities. The activities carried out are directed and have the desire to be given rewards or flattery words so that the studio is more visible in the eyes of the public. Likewise, they as people in the studio will distance themselves from punishment, this makes a bad impact in the studio in the eyes of the community and becomes a race in avoiding all things that smell negative. Hidden curriculum in general can be described as a byproduct of education inside or outside of school, especially the results learned, but not explicitly stated as an objective.

There are two aspects that can affect the hidden curriculum, namely the first aspect is relatively fixed is the ideology, beliefs, cultural values of society that influence the educational institutions, including determining what culture is appropriate and not deserved to be passed on to the nation's generation. One example that occurs in the Ragil Entertainment Entertainment community is its ability, and the second is that aspects that can change include supporting organizational variables, the social and cultural systems of the art community object, social interaction and its close relationship, culture by preserving Rampak Kendang and can be learned by many children.

\section{References}

[1] E. R. Pratiwi, "Pengaruh Hidden Curriculum Terhadap Pembentukan Karakter Siswa Di SMP IT Masjid Syuhada' Kotabaru Yogyakarta," J. Pendidik. Agama Islam, vol. 14(2), pp. 324-326, 2017.

[2] J. Martin, "What Should We Do with a Hidden Curriculum When We Find One?The Hidden Curriculum and Moral Education," McCutchan Publ. Corp., 1983.

[3] W. Sanjaya, Kurikulum dan Pembelajaran (Teori dan Praktik Pengembangan Kurikulum Tingkat Satuan Pendiidkan). Jakarta: Kencana Prenada Media Group, 2008.

[4] L. Simatupang, Pergelaran: Sebuah Mozaik Penelitian Seni-Budaya. Yogyakarta: Jalasutra, 2013.

[5] B. Yudoyono, Gamelan Jawa: Asal Mula Makna Masa Depannya. Jakarta: PT. Karya Unipress, 1984. 
[6] P. Novitasari, "Peran Guru dalam Pelaksanaan Hidden Curriculum terhadap pencapaian tujuan Pendidikan agama Islam di MAN 1 Bandar Lampung," Program Pascasarjana Institut Agama Islam Negeri Raden Patah Intan Lampung, 2017.

[7] S. H. Wardizal, "Peran Wanita Dalam Seni Pertunjukan Tradisional Minangkabau Di Tengah Perubahan Kehidupan Sosio Kultural Masyarakatnya. Denpasar," KALANGWAN J. Seni Pertunjuk., vol. 4(1), pp. 63-70, 20184.

[8] T. R. Rohidi, Metodologi Penelitian Seni. Semarang: CV Cipta Prima Nusantara, 2011.

[9] G. Sulasman and Setia, Teori-teori Kebudayaan. Bandung: Pustaka Setia.

[10] L. Moleong, Metodologi Penenlitian Kualitatif. Bandung: PT RemajaRosdakarya, 2007. 